is described. W. L. Bragg gave a paper by himself, C. Sykes and A. J. Bradley on the work carried out at Manchester on the same problem.

C. H. Desch (National Physical Laboratory) gave a paper on age hardening alloys with special reference to their resistance. A. J. Bradley also mentioned his recent work on the crystal structure of the permanent magnets in the iron-nickel-aluminium alloy series, and in consequence of this a very definite model was proposed for the age hardening process, the atoms present in solid solution being supposed to collect together in groups still forming part of the erystal lattice of the original alloy. Such a process sets up intense strain, and hence hardens the alloy.

The final day was devoted to a discussion of the resistance of thin metallic films. After an initial paper by G. I. Finch (Imperial College of Science and Technology) on the structure of these films as revealed by electron diffraction, E. T. S. Appleyard gave a paper on work carried out in Bristol on their resistance, and A. Féry and M. J. Bernamont followed with papers on work done in Paris. A distinction was drawn between metals such as the alkalis which may form a fairly uniform layer over the surface upon which they are deposited, and metals such as mercury which apparently form islands. The mechanism by which the atoms can wander on a surface and form islands was discussed by J. E. Lennard-Jones. A point upon which no agreement was reached was the negative temperature coefficient of resistance of some films, and whether it is due to occluded gases.

Full reports of the principal papers given at this meeting, together with a summary of the discussions and the main conclusions reached, will be published in September in a special number of the Proceedings of the Physical Siociety.

\title{
Beginnings of Western Science in Japan
}

$\mathrm{A}^{\mathrm{T}}$ T the fellows' dinner held at University College, London, on April 30, Prof. Joji Sakurai, emeritus professor in the Imperial University of Tokyo, president of the Imperial Academy and of the National Research Council of Japan, replied to the toast of the new honorary fellow. In the course of his remarks, Prof. Sakurai said :

"If what I have been able to do in my work in Japan is at all creditable, the credit must be traced back to my education in England and, first and most of all, to the scientific training I received in University College during the five years extending from 1876 until 1881. Dr. Alex. W. Williamson, renowned throughout the whole world for his classical investigation on the formation of ethers and renowned also for his remarkably keen insight into the atomic constitution of matter, was then professor of chemistry, and it is needless for me to say how highly I value the scientific training I received from him. I was taught physics by Prof. Carey Foster and Dr. Oliver Lodge, and the knowledge of physics thus acquired was' a great help to me in following the remarkably rapid development of physical chemistry which was soon to come.

"It was, however, not the scientific training alone that $I$ received in England. The five years of my student life in England were in the latter half of Queen Victoria's reign, a period which is one of the most glorious in the whole history of England. It was a period in which some of the greatest and most illustrious of men and, also, of women were to be met with in almost every field of human activity. As statesmen and orators, Lord Beaconsfield and the grand old man-Mr. Gladstone-were shining like stars of first magnitude; Tennyson was being adored as poet laureate, Ruskin as a writer and critic and George Eliot as a feminine novelist of unusual talent ; Charles Darwin was enjoying to see his life-long labours bearing fruit, Herbert Spencer was laying a scientific foundation of sociology, whilst Henry Irving and Ellen Terry were, night after night, drawing crowds of enthusiastic audiences to the Lyceum.

"Having had the rare fortune of being in England at such a glorious time, I could not, and would not, confine myself to scientific studies alone, but wishing to look upon England with more widely opened eyes I studied something of English history, of English literature, of English art and, even, of English drama. At the same time, I had the great good fortune of making some very dear and life-long friends and, through them, of knowing something of English homes and of mixing more or less in English society, all of which combined in enabling me to get a fairly accurate idea of English culture, and it was this-the knowledge of English culture -which has proved to me to be of inestimable value throughout the whole of my later life. If, therefore, my work in Japan is worth mentioning, it is to be wholly attributed to the scientific and cultural training I was able to receive during the five years of my student life in England.

"I should like to make a short reference to an important fact in the recent history of Japan, concerning Anglo-Japanese cultural relations. A few years before the Restoration, that is about seventyfive years ago, a group of five young men from Choshu came over to London in one of the sailing vessels owned by Messrs. Jardine, Matheson \& Co. of Yokohama, whose correspondents in London were Messrs. Matheson \& Co. The object of these young men was to make a general study and observation of Western civilization and when, after a long voyage round the Cape of Good Hope, they arrived in London they were introduced to an elderly gentleman who took every care of them and helped them in every way in their study and observation. This elderly gentleman was no other than Dr. Williamson of University College under whom, as I said before, I was a student for five years. As to what made him particularly interested in these young men and in Japan I can say nothing, but I remember him. often telling me that Japan was England of the East, by which, as it appeared to me, he meant something more than mere geographical likeness of the two island empires.

"Returning to the five young men, two of them went back to Japan in the following year in consequence of important developments at home, and 
plunged themselves in the great political turmoil which soon led to the Restoration. One of these two men was Shunsuke Ito-later, Prince Hirobumi Ito -who was generally regarded as the founder of modern Japan, and the other was Bunta Inouelater, Marquis Kaoru Inoue-who was cabinet minister in the Meiji Government on several occasions. The other three also greatly distinguished themselves and occupied important positions in the new Government. Of these, Yasuke Nomura-later, Viscount Masaru Inoue-who, by the way, was living with Dr. Williamson's family for several years, laid and ran the first railways in Japan, Yozo Yamao-later, Viscount Yozo Yamao-greatly contributed towards laying the foundation of technical education, and Kinsuke Endo was, if I remember rightly, the first master of the mint.

"Now, the most important item in the policy of the Meiji Government was the transplantation of Western sciences, the elements of which were taught by missionaries. But as time came for higher scientific education, need was felt for teachers properly equipped with the necessary knowledge and ability, and the Government naturally decided to call these teachers from England. Strange as it may appear to-day, these calls were made through the firm of Messrs Jardine, Matheson \& Co. in Yokohama, which transmitted them to their correspondents in London, and the latter invariably consulted with
Dr. Williamson or somebody else named by him. The fact that Dr. Williamson intervened in the transaction of this important business was most fortunate for Japan, for the young scientific men recommended by him, either directly or indirectly, for the Japanese posts all proved themselves to be most capable teachers of science, among whom the names of William Ayrton, Edward Divers, Alfred Ewing, John Milne and John Perry may especially be mentioned as those who, later, all became fellows of the Royal Society of London. These pioneers of science in Japan taught their students to study science for its own sake, themselves setting examples by numerous brilliant researches and thereby greatly stimulating the spirit of original scientific work. I am particularly happy to have been given an oppor. tunity this evening of making reference to this little piece of history, which is almost completely unknown, but which shows how much Japan owes to Dr. Williamson and, through him, University College and England for the valuable help given in the earlier and most important stages of development of modern sciences in Japan.

"Ever since the foundation of Ramsay fellowships in 1920, Japanese Ramsay fellows have, if I remember rightly, without a single exception come to work under Prof. Donnan, with whom the cultural obligations Japan owes University College and England have thus been happily revived".

\section{International Association for European Ethnology and Folklore}

\section{CONFERENCE at Edinburgh}

$\mathrm{T}$ HE International Association for European Ethnology and Folklore was formed in November, 1935. Its first Congress was held in the New College, Edinburgh, on July 14-21. The Scottish Anthropological and Folklore Society acted as hosts. Seventy-six delegates registered as members of the Congress, the countries represented being Great Britain and Ireland, Sweden, Norway, Denmark, Finland, Lithuania, Estonia, Holland, Belgium, Switzerland, and the United States.

At the opening of the Congress, the presidential address was delivered by Prof. Herman Geiher, of the University of Uppsala. Thirty-one papers were read. Those dealing with folklore included "Remarks upon Methods of Surveying and Making Distribution Maps in the fields of Dialect and Folklore", by the president; "Scottish and Norwegian Ballads", by Prof. K. Liestøl, Oslo ; "Norse and Gaelic Folklore", by Dr. R. Th. Christiansen, Oslo; "The Stars in Eskimo Folklore", by Prof. W. Thalbitzer, Copenhagen; "Rites", by Dr. C. W. von Sydow, Lund ; and "The Origins of the Duckingstool", by Prof. J. W. Spargo, Northwestern University, U.S.A.

Papers of technological and museum interest were "Simple Agricultural Implements of England", by Mr. R: U. Sayce, Manchester ; "The Early History of Vehicles in Northern Europe", by Dr. G. Berg, Stockholm ; "The Irish House", by Dr. Ảke Campbell, Uppsala ; and "Scandinavian Folk Museums", by Prof. Sigurd Erixon, Stockholm.
On the linguistic side, Dr. W. Grant, Aberdeen, dealt with "The Scottish National Dictionary"; Mr. J. C. Catford, Edinburgh, with "Scottish Dialects and the Proposed Linguistic Atlas of Scotland" ; Dr. G: .S. Lowman, Brown University, U.S.A., with "The Linguistic Survey in the U.S.A. and Canada". Dr. R. Nordenstreng, Uppsala, made some helpful suggestions as to the solution of an ethnological problem in his paper on "The Riddle of the Finns, Frisians, and Fair Broad-heads".

Among papers of particularly Scottish interest was that by Mrs. M: Macleod Banks, president of the Folklore Society, on "The Three Marts and the Man with the Withy",

During the Congress, a 'ceilidh', arranged by Miss J. Bruce, secretary of Highland Home Industries, Ltd., was performed by a group of Gaelic-speaking women; and a display of authentic Scottish country dancing was given at Roslin by a team of 'bondager's' under the supervision of Mr. Ion C. B. Jamieson.

Throughout the congress, there was on view an exhibition of ethnological and folkloristic material, of which the outstanding feature was the display of photographs and drawings of house-types and domestic and agricultural implements selected from the collection of the Irish Folklore Commission. Other exhibits were by the Landsmålsarkivet, Uppsala; the Nordic Museum, Stockholm; H.M. Office of Works; and Highland Home Industries, Ltd. 